Egypt. Poult. Sci. Vol. (41) (III): (659-673) (2021)

\title{
IMPACT OF PROPOLIS SUPPLEMENTIONS ON GROWTH PERFORMANCE AND PHYSIOLOGICAL RESPONSES IN JAPANESE QUAIL
}

\author{
Fouad, W.; Kassab, A. Y. and M. M. Badr
}

Dep. of Poult. Prod., Fac. of Agric., New Valley Uni., Egypt.

Corresponding author: Walid Fouad, E-mail: walidfouad1971@agr.nvu.edu.eg

Received: 25/08/2021

Accepted: $29 / 09 / 2021$

\begin{abstract}
To investigate the response of feeding Japanese quail chicks to propolis supplementation on growth performance, blood constituents, hormones, immunity, antioxidant, carcass characteristics and bacterial count, one hundred and twenty, oneweek-old Japanese quail chicks were divided to four dietary groups with three replicates (10 birds). The first group fed a basal diet, while the groups $2^{\text {nd }}, 3^{\text {rd }}$ and $4^{\text {th }}$ were fed with 200, 400 and $600 \mathrm{mg}$ of propolis/kg diet until the age of six weeks. The results showed a significant improvement in feed intake, body weight, body weight gain and feed conversion with increasing of propolis supplementation. All treatments increased significantly $(\mathrm{P}<0.01)$ percentage of dressing and internal organs than the Control birds. Propolis supplementation significantly $(\mathrm{P}<0.01)$ increased blood components; $\mathrm{Hb}$, RBC, PCV, WBCs, lymphocyte, total protein, globulin, albumin, glucose, high density lipoprotein, total antioxidant capacity, $\operatorname{IgM}, \operatorname{IgG}$, thyroid hormones $\left(\mathrm{x} 10^{3}\right)$ as compared to control group and decreased total lipids, plasma cholesterol, LDL, ALT, AST. Moreover, propolis decreased the Intestinal total anaerobic, aerobic microflora counts and total coliform compared to control group. There was no effect on monocytes, eosinophils and neutrophils as compared to control group. The results showed that supplementation of propolis at levels of 200,400 and $600 \mathrm{mg}$ of propolis $/ \mathrm{kg}$ feed improves growth performance, blood components, antioxidant indices, thyroid hormones, immune parameters and carcass characteristics.
\end{abstract}

Keywords: propolis - Japanese Quail- growth - blood - immunity. 


\section{INTRODUCTION}

Studies are being conducted on alternative products that can promote growth, improve feed utilization, and maintain gut health (Zhang et al. 2005). One alternative might be to incorporate propolis into in bird diets. Propolis is a resin that honey bees (Apis mellifera caucasica) collect from buds and bark of certain trees and plants. (Moreno, et al. 2000; Dimov et al. 1991). Several of chemical compounds contained in Propolis like inorganic compounds, steroids, amino acids and polyphenols (phenolic aldehydes, aglycone, phenolic acids, alcohols, esters and ketones). Several biological properties, including antibacterial, antiviral, antifungal, antioxidant, hepatoprotective and immunostimulating activities of propolis have been reported and therefore propolis supplements are used as an additive in poultry feed (Tatli Seven, 2008). This has been confirmed by Mathivanan et al. (2013) that propolis has a beneficial effect on feed intake, conversion and daily gain in poultry. Also, beneficial effect against a variety of Gram-negative bacteria and some Gram-positive bacteria using propolis according to Velikova et $a l ., 2000$. It is clear that propolis can be considered as substitutional to the use of food antibiotics (Itavo et al., 2011). Indeed, several researchers (Cetin et al., 2010; Fischer et al., 2010) have demonstrated that propolis is capable of inducing immunological effects in animals via the synthesis of antibodies, affecting macrophage activation and lymphoid organ weight. Numerous studies have recorded the useful effect of propolis on the immune response and growth in poultry (Shalmany and Shivazad, 2006; Tatli Seven et al., 2008; Babaei et al., 2016). Positive effect of the supplemental propolis added to chick feed led to an improvement in growth performance as reported by (Sherif and El-Saadani 2017; El-Naggar and AbdelKhalek 2019). Due to the lack of information about the use of propolis in growth feed for quail birds. The aim of this study is to determine the impact of propolis supplementation added to quail feed on growth performance and physiological responses in Japanese quail.

\section{MATERIALS AND METHODS}

The experiment was carried out on a private farm in El Kharga city, New Valley Governorate, Egypt from September to October 2018 .

\section{Experimental Design}

One hundred and twenty, Seven-day old chicks of Japanese Quails were having nearly equaled live weights and randomly distributed into four treatments groups housed in 3 replicate pens (each contained 10 chicks). Chicks were raised under similar managemental and hygienic conditions. Feed and water were supplied ad libitum throughout the experimental period which ended at 6 wks of age. The basal diet (control) has been formulated to meet the nutrient requirements of chicks and fed $23 \% \mathrm{CP}$ and $2800 \mathrm{Kcal}$. The composition of the basal diet is given in Table (1a) and the chemical composition of propolis recorded in Table (1b). Chicks in the first group were fed on a basal diet and considered as a control group, while the other three groups 2, 3 and 4 were fed on a basal diet supplemented with 200, 400 and $600 \mathrm{mg}$ propolis $/ \mathrm{kg}$ feed respectively .At the 
propolis - Japanese Quail- growth - blood - immunity.

beginning of the experiment (1 week) birds were individually weighed $(\mathrm{g})$ and at the end of the experiment (6 weeks). Feed intake for each replicate, body weight gain (BWG) and feed conversion (FCR) were recorded as $\mathrm{g}$ feed/g gain.

At 6 weeks of age, five birds from each treatment were selected randomly, weighed and slaughtered for carcass dressing. The carcass organs weights (carcass, heart, liver, gizzard, spleen and intestinal) were expressed as percentage of the live weight. Intestinal anaerobic and aerobic microflora counts were determined. Total anaerobic count, total coliform count and aerobic plate count (APC) were carried out according to American Public Health Association (A.P.H.A, 1985). Ten blood samples were collected from each experimental group at the time of slaughter and divided into two parts. The first part was collected in heparin tubes while the second part was collected in non-heparin tubes to obtain serum. Fresh blood aliquots were used to determine hematological parameters [white blood cells (WBCs), red blood cells (RBCs), hemoglobin ( $\mathrm{Hb})$, and Packed cells volume (PCV)]. Serum was obtained from blood samples stored at 20 ${ }^{\circ} \mathrm{C}$ for later analysis. Blood biochemical parameters such as: total protein, albumin, globulin, total lipids, cholesterol, glucose concentration, lowdensity lipoprotein (LDL), high-density lipoprotein (HDL), alanine aminotransferase ALT, aspartate aminotransferase (AST) and total antioxidant capacity TAC in blood serum were determined using a commercial kit (Biolabosa As. Frances). Blood hormones, thyroxine (T4), triiodothyronine (T3) and immune parameters; Immunoglobulin $\mathrm{G}$ (IgM) and immunoglobulin $\mathrm{G}$ (IgG) were determined by enzyme immunoassay using commercial kits.

\section{Statistical analysis data}

Statistical analysis data obtained from this study were analyzed using the Statistical Analysis System (SAS, 2002) general linear model procedure, using one-way ANOVA as in the following model: $\mathrm{Yik}=\mu+\mathrm{Ti}+$ eik Where, $\mathrm{Y}$ is the dependent variable; $\mu$ is the general mean; $\mathrm{T}$ is the effect of experimental treatments; and $\mathrm{e}$ is the experimental random error. Significant differences between means were defined at $\mathrm{P}<0.05$ compared using Duncan's multiple range test (Duncan, 1955).

\section{RESULTS AND DISCUSSION}

\section{Growth performance and carcass}

Propolis supplementation effect on feed intake, body weight, body weight gain, and feed conversion ratio for Japanese quail chicks are shown in Table (2). Propolis supplementation improved feed conversion ratio and increased significantly $(p<0.01)$ feed intake, body weight and body weight gain comparing to control.Supplementation of propolis at 200,400 and $600 \mathrm{mg}$ propolis $/ \mathrm{kg}$ of diet led to an increase in body weight by 4.03 , 8.85 and $18.9 \%$, feed intake by 1.66 , 3.06 and $8.46 \%$, body weight gain by $5.05,11.04$ and $23.58 \%$, of the control group, respectively. Result showed that birds fed diet supplemented with $600 \mathrm{mg}$ propolis $/ \mathrm{kg}$ of diet had the higher feed intake, body weight, body weight gain and the best in feed conversion compared with the other dietary treatments. This improvement in the current study may be due to a reduction bacterial load causing disease in the intestine and an 
Fouad, W.;et al.

improvement in the status of the intestinal lumen, resulting in increased absorption and utilization of nutrients. moreover, the high content of phenolic acids and flavonoids in propolis has positive effects on health and metabolism because it improves beneficial microbes in the gut (Viuda-Mattos et al., 2008). As pointed out by Moreno, et al. 2000; Dimov et al. 1991. Several of chemical compounds contained in Propolis like inorganic compounds, steroids, amino acids and polyphenols (phenolic aldehydes, aglycone, phenolic acids, alcohols, esters and ketones).Many biological properties, including antibacterial, antiviral,antifungal, antioxidant, hepatoprotective and immunostimulating activities of propolis have been reported. The results are consistent with those reported by Sherif and El-Saadani (2017) which showed that Increasing propolis level increased body weight (BW) and body weight gain (BWG). On the other hand, El-Naggar and Abdel-Khaleq (2019) showed that ducklings fed diet supplemented with different levels of propolis had significantly greater BW, BWG and better feed conversion as compared to control.

Data presented in Table (3) showed that influence of dietary different levels of propolis supplementation on the relative weights of dressing, heart, liver, gizzard, spleen and intestinal. Results showed that relative weight of the internal organs of Japanese quail of treated groups were significantly $(p<0.01)$ increased with increase of propolis level and higher than control group. In addition, the treated with $600 \mathrm{mg}$ propolis $/ \mathrm{kg}$ of diet had the best carcass weight compared with other dietary treatments. The improvement from dressings in propolis-supplemented treatments could be attributed to the increase in body weight at slaughter as it has been suggested that the high value of the weight of the living body is attracted and can be related to the physiological state of the high value of the carcass weight (Ojewole et al., 2000).This important production of immune cells may also be due to the antioxidant activity of propolis which is a rich source of vitamins ( Moreira, 1986), enzymes (Khalil and El-Sheikh, 2010) and other biological components including fatty acids, amino acids and flavonoids. (Wagh, 2013) who showed that propolis can be used as a natural growth promoter in poultry (Attia et al., 2015).The results are consistent with those reported by Sherif and El-Saadany (2017) which showed that the relative carcass weight and lymphoid organ weights were significantly improved $(\mathrm{p}<0.01)$ by increasing the level of propolis. Similar results were confirmed by Elnaggar and Abd El-khalek (2019) who showed that ducklings fed a basal diet supplemented with different levels of propolis resulted in a significant increase in the ratio of dressing and total edible parts compared to the control.

\section{Blood indices}

The data in Tables $(4,5)$ show that different supplemental dietary levels of propolis have a significant $(\mathrm{P}<0.01)$ increase in the hematological traits of quail parameters (Red Blood Cells, Hemoglobin $(\mathrm{Hb})$, Packed cells volume (PCV), white blood cells (WBCs)) and lymphocyte compared to the control. Feeding diets with different levels of propolis supplement had a significant $(\mathrm{P}<0.01)$ increase in the blood 
propolis - Japanese Quail- growth - blood - immunity.

biochemical parameters of quail (total protein, albumin, globulin, glucose concentration, $\mathrm{HDL}$ and $\mathrm{T}_{4}, \mathrm{~T}_{3}$ hormone while total serum lipids, cholesterol, LDL, ALT, and AST were significantly $(\mathrm{P}<0.01)$ decreased compared to the control group. Moreover, antioxidant indices (total antioxidant capacity TAC ) and immune indices (IgG), (IgM) were higher in birds of Japanese quail fed basal diets supplemented with different levels of propolis compared to the control group. Furthermore, no significant effects of different levels of propolis were detected on monocytes, eosinophils and neutrophils as compared to control group. Red blood cells are responsible for the manufacture of hemoglobin, and the transport of carbon dioxide and oxygen in the blood, so higher values indicate greater potential for these functions and better health (Olugbemi et al. 2010).

Our results are in agreement with that of Attia et al. (2014) which showed that it increases erythrocytes and hemoglobin by continuous or intermittent addition of propolis in broiler rations at $300 \mathrm{mg} / \mathrm{kg}$. The same results for Sasso chickens obtained by Omar et al. (2014), Sherif and El-Saadani (2016) For laying hens. The beneficial effect of propolis on protein fractions may be due to the hepatoprotective effect which appears to preserve the body protein from degeneration and anabolic effect in favor of protein synthesis. In the current study, it may be that the improvement in protein fractions and globulin concentration that has been observed may be because chicks livers will be able to synthesize enough globulin for immune action that keeps the body protein from degeneration (Khalil, 2006). These results are consistent with the results of Abdel-Kareem and ElSheikh (2015) who showed that the addition of propolis in the layer ration (250, 500 and $1000 \mathrm{mg} / \mathrm{kg}$ diet) increases total protein, globulin and albumin.Similarly, propolis has shown positive effects on the immune response and antibodies in poultry (Yang et al., 2008; PopielaPleban et al., 2012). This may be attributed not only to the specific antibacterial effect of propolis with positive effects on metabolism (Aygun et al., 2012), but also to its antifungal (Sforcin, 2007), antiparasitic (Freitas et al., 2006), and antiviral (Gekker et al., 2005), immunomodulatory (Dimov et al., 1992), anti-inflammatory (Dobrowolski et al., 1991), and antioxidant (Krol et al., 1990) effects. These results agree in part with those of Kacániová et al. (2012). Additional evidence was found to improve the health of the presented chicken by lowering serum cholesterol, triglycerides, creatinine, urea and asparatate aminotransferase compared to the control, indicating improved kidney and liver function and lipid metabolism. This may be due to the effect of the propolis on the catabolic muscles. In addition, Omar et al (2002) found that the improvement in erythrocytes, hemoglobin, PCV and protein by propolis could be due to the direct effect of the anabolic action of the synthetic protein, which can protect the protein body from degeneration. The effect of propolis on plasma metabolites can be attributed to its vitamin, mineral and phospholipid contents (Leja et al., 2007) and its antioxidant effects (Šarić et al., 2009). The effects of propolis on cholesterol are in agreement with those reported by Fuliang et al. (2005). This may be due to 
Fouad, W.;et al.

the effect of propolis on lipid metabolism (Matsui et al., 2004), and there was a significant $(\mathrm{p}<0.01)$ decrease in the liver enzymes, AST and ALT by increasing propolis in quail rations. Galal et al. (2008) noted the same finding that ALT and AST activities were significantly reduced by adding propolis to the diet layer at 100 and $150 \mathrm{mg} / \mathrm{kg}$ diets. Similarly, Abdel-Kareem and El-Sheikh (2015) found that when fed chickens with diet containing propolis at 250, 500 and $1000 \mathrm{mg} / \mathrm{kg}$, liver enzymes (AST and ALT) decreased.The present results regarding the decreased activities of transaminases in the blood can be attributed to the high biological activity resulting from the addition of Propolis to its content of nutritional values that may prevent lipid oxidation. These results agreed with Cetin et al. (2010) and Freitas et al. (2011), who found an increase in the concentration of $\operatorname{IgM}$ and IgG due to the addition of propolis compared to the control group and the improvement in the immune status may be due to propolis because it contains flavonoid components that raise cytokines. These cytokines stimulate the activities of $\mathrm{B}$ lymphocytes that will be able to produce immunoglobulins (Fritas et al., 2011).

Our results were confirmed by Mahmoud et al. (2015) who found a significant increase in total antioxidant capacity (TAC ) as a result of propolis supplementation in broiler rations of 250 , 500 and $750 \mathrm{mg} / \mathrm{kg}$, which may be due to their higher flavonoid conte. The same result was observed with Shreif and ElSaadany (2017) who showed that there is a positive effect of supplementing propolis to the chicks' diet, especially on the immune status, physiological status and antioxidants. Moreover, adding propolis/kg diet can improve the health of chicks. The same results were obtained by Elnaggar and Abd El-khalek (2019) for ducklings.

\section{Bacteria count}

The results of the intestinal microbial count of Japanese quail are presented in Table (6). All propolis levels led to a decrease in the total anaerobic count, total aerobic count and total microform compared with the control group. In this study, the beneficial effect on the number of gut microbes may be due to the addition of propolis to bird feed because it contains flavonoid and phenol components, as well as to its antimicrobial activity (Tatli Seven et al., 2009). Moreover, the ability of propolis can be explained by the strong antibacterial effect and its content of micro-nutrients and beneficial which may have positive effects on the health of birds (Canogullari et al., 2009; Shreif and El-Saadany, 2017; Elnaggar and Abd Elkhalek, 2019 ).

\section{CONCLUSION}

It can conclusion using propolis for growing Japanese quail diet could be highly benfecal and improves performance, blood components, hormones, immunity parameter, antioxidant indices and carcass characteristics, therefore, propolis could be an available feed additives supplementation with $600 \mathrm{mg} / \mathrm{kg}$ will gine the quail diet effect. 
Table (1a): Composition of the experimental diet- through the growing period.

\begin{tabular}{|l|c|}
\hline \multicolumn{1}{|c|}{ Ingredients } & Percentage in diet \\
\hline Corn & 50.70 \\
Soybean meal & 42.52 \\
Vegetable oil & 2.00 \\
Di-Calcium phosphate & 0.72 \\
Calcium carbonate & 1.25 \\
Salt & 0.33 \\
Vitamin premix1 & 0.25 \\
Mineral premix2 & 0.25 \\
DL-methionine & 0.13 \\
L-Threonine & 0.11 \\
Sand & 1.74 \\
\hline Nutrient composition & \\
\hline Crude protein (\%) & 23.00 \\
Metabolizable Energy (Kcal kg-1) & 2800 \\
Available phosphorus (\%) & 0.29 \\
Calcium (\%) & 0.77 \\
Sodium (\%) & 0.15 \\
Methionine (\%) & 0.48 \\
Threonine (\%) & 0.98 \\
Methionine + Cysteine (\%) & 0.85 \\
Lysine (\%) & 1.28 \\
\hline
\end{tabular}

1 Provides per $\mathrm{kg}$ of diet, Vitamin A: $3125 \mu \mathrm{g}$, Vitamin K3: $5 \mathrm{mg}$, Vitamin D3: $75 \mu \mathrm{g}, \alpha-$ tocopherol acetate: $50 \mathrm{mg}$, Vitamin B1: $3 \mathrm{mg}$, Vitamin B2: $6 \mathrm{mg}$, Vitamin B6: $5 \mathrm{mg}$, Vitamin B12: $0.003 \mathrm{mg}$, Niacin: $50 \mathrm{mg}$, Folic acid: $1 \mathrm{mg}$, Pantothenic acid: $10 \mathrm{mg}$, 12Biotin: $0.1 \mathrm{mg} .2$ Provides per kg of diet, Cu: $5 \mathrm{mg}$, I: $2 \mathrm{mg}$, Co: $0.5 \mathrm{mg}$, Se: $0.15 \mathrm{mg}$, Mn: $90 \mathrm{mg}$, Fe: $50 \mathrm{mg}, \mathrm{Zn}$ : $70 \mathrm{mg}$. 
Fouad, W.;et al.

Table (1b): The major compounds of Egyptian propolis

\begin{tabular}{|l|c|}
\hline Proximate analysis of propolis & \\
\hline Crude protein & 1.9 \\
Carbohydrates & 1.7 \\
Ash & 4.1 \\
Fat & 1.4 \\
Essential oils & 4.1 \\
Stearic\% & 7.2 \\
Palmitic\% & 12.9 \\
Oleic\% & 13.3 \\
Linolenic\% & 0.79 \\
Linoleic\% & 1.9 \\
Palmitoleic\% & 9.1 \\
Flavonoids (Total) \% & 27.9 \\
\hline
\end{tabular}

Table (2): Effect of propolis on body weight, body weight gain, feed intake and feed conversion of Japanese quail.

\begin{tabular}{|c|c|c|c|c|c|c|}
\hline $\mathrm{T}_{\text {Traits }}^{\text {Treatments }}$ & control & $\begin{array}{c}\text { Propolis } \\
200 \\
\mathrm{mg} / \mathrm{kg} \\
\text { feed }\end{array}$ & $\begin{array}{c}\text { Propolis } \\
400 \\
\text { mg/kg } \\
\text { feed }\end{array}$ & $\begin{array}{c}\text { Propolis } \\
600 \\
\text { mg/kg } \\
\text { feed }\end{array}$ & $\begin{array}{c}\text { Pooled } \\
\text { SEM }\end{array}$ & $\begin{array}{c}\mathbf{P} \\
\text { value }\end{array}$ \\
\hline Initial weight ( $\mathrm{g}$ ) & $3 / .14$ & 37.13 & 37.04 & 37.03 & 0.14 & 0.895 \\
\hline Final body weight ( g) & $192.12^{d}$ & $212.01^{\mathrm{c}}$ & $230.96^{b}$ & $251.06^{\mathrm{a}}$ & 0.24 & 0.001 \\
\hline Feed intake $(\mathrm{g})$ & $560.84^{d}$ & $598.43^{c}$ & $617.03^{b}$ & $637.84^{a}$ & 1.22 & 0.001 \\
\hline Body weight gain ( g) & $154.97^{\mathrm{d}}$ & $174.87^{\mathrm{c}}$ & $193.92^{b}$ & $214.02^{\mathrm{a}}$ & 0.19 & 0.001 \\
\hline Feed conversion (g feed/g gain) & $3.62^{\mathrm{a}}$ & $3.42^{b}$ & $3.18^{\mathrm{c}}$ & $2.98^{\mathrm{d}}$ & 0.01 & 0.001 \\
\hline
\end{tabular}

$a, b, c$. means with the different letters in the same row are significantly different $(\mathrm{P} \leq 0.01)$;

$\mathrm{SEM}=$ Standard error of means. 


\begin{tabular}{|l|c|c|c|c|c|c|}
\hline \multicolumn{1}{|c|}{ Treatments } & control & $\begin{array}{c}\text { Propoli } \\
\mathbf{5 ~ 2 0 0} \\
\mathbf{m g} / \mathbf{k g} \\
\text { feed }\end{array}$ & $\begin{array}{c}\text { Propoli } \\
\mathbf{5 ~ 4 0 0} \\
\mathbf{m g} / \mathbf{k g} \\
\mathbf{f e e d}\end{array}$ & $\begin{array}{c}\text { Propolis } \\
\mathbf{6 0 0} \\
\mathbf{m g} / \mathbf{k g} \\
\mathbf{f e e d}\end{array}$ & $\begin{array}{c}\text { Pooled } \\
\text { SEM }\end{array}$ & P value \\
\hline Dressing (\%) & $64.73^{\mathrm{c}}$ & $69.84^{\mathrm{b}}$ & $73.56^{\mathrm{a}}$ & $75.28^{\mathrm{a}}$ & 0.59 & 0.001 \\
Heart \% & $0.79^{\mathrm{d}}$ & $0.81^{\mathrm{c}}$ & $0.83^{\mathrm{b}}$ & $0.85^{\mathrm{a}}$ & 0.01 & 0.001 \\
Liver \% & $1.77^{\mathrm{d}}$ & $1.96^{\mathrm{c}}$ & $2.02^{\mathrm{b}}$ & $2.18^{\mathrm{a}}$ & 0.01 & 0.001 \\
Gizzard \% & $1.85^{\mathrm{d}}$ & $1.96^{\mathrm{c}}$ & $2.23^{\mathrm{b}}$ & $2.58^{\mathrm{a}}$ & 0.01 & 0.001 \\
Spleen (\%) & $0.043^{\mathrm{d}}$ & $0.045^{\mathrm{c}}$ & $0.053^{\mathrm{b}}$ & $0.055^{\mathrm{a}}$ & 0.0004 & 0.001 \\
Intestinal \% & $2.94^{\mathrm{c}}$ & $2.98^{\mathrm{b}}$ & $2.98^{\mathrm{b}}$ & $3.06^{\mathrm{a}}$ & 0.01 & 0.001 \\
\hline
\end{tabular}

Table (3): Effect of propolis on some relative carcass characteristics of Japanese quail a,b,c. means with the different letters in the same row are significantly different $(\mathrm{P} \leq 0.01)$; $\mathrm{SEM}=$ Standard error of means

Table (4): Effect of propolis on some hematological blood, antioxidant indices and immune indices of Japanese quail.

\begin{tabular}{|c|c|c|c|c|c|c|}
\hline Treatments & control & $\begin{array}{c}\text { Propolis } \\
200 \\
\text { mg/kg } \\
\text { feed }\end{array}$ & $\begin{array}{c}\text { Propolis } 400 \\
\text { mg/kg feed }\end{array}$ & $\begin{array}{c}\text { Propolis } \\
600 \\
\text { mg/kg } \\
\text { feed }\end{array}$ & $\begin{array}{c}\text { Pooled } \\
\text { SEM }\end{array}$ & $\begin{array}{c}\mathbf{P} \\
\text { value }\end{array}$ \\
\hline $\mathrm{RBC}(106 / \mathrm{mm} 3)$ & $3.23^{\mathrm{d}}$ & $3.42^{\mathrm{c}}$ & $4.01^{b}$ & $4.06^{\mathrm{a}}$ & 0.01 & 0.001 \\
\hline $\mathrm{HB}(\mathrm{g} / \mathrm{dl})$ & $16.40^{\mathrm{d}}$ & $17.00^{\mathrm{c}}$ & $18.23^{\mathrm{b}}$ & $19.37^{\mathrm{a}}$ & 0.14 & 0.001 \\
\hline PCV\% & $36.63^{d}$ & $39.13^{c}$ & $42.17^{\mathrm{b}}$ & $44.30^{\mathrm{a}}$ & 0.17 & 0.001 \\
\hline $\mathrm{WBC}(103 / \mathrm{mm} 3)$ & $41.45^{\mathrm{c}}$ & $43.39^{b}$ & $44.69^{\mathrm{ab}}$ & $45.09^{\mathrm{a}}$ & 0.30 & 0.001 \\
\hline Lymphocytes, (\%) & $51.77^{\mathrm{b}}$ & $51.83^{b}$ & $52.33^{\mathrm{b}}$ & $53.27^{\mathrm{a}}$ & 0.26 & 0.022 \\
\hline Neutrophils (\%) & 35.53 & 35.37 & 34.87 & 33.96 & 0.41 & 0.078 \\
\hline Eosinophils, (\%) & 2.93 & 2.93 & 2.83 & 2.67 & 0.07 & 0.137 \\
\hline Monocytes, (\%) & 9.77 & 9.87 & 9.97 & 10.10 & 0.21 & 0.657 \\
\hline $\mathrm{TAC}(\mathrm{mg} / \mathrm{dl})$ & $413.21^{c}$ & $415.59^{c}$ & $422.83^{b}$ & $430.50^{\mathrm{a}}$ & 0.73 & 0.001 \\
\hline $\mathrm{IgG}(\mathrm{mg} / 100 \mathrm{ml})$ & $818.53^{c}$ & $820.33^{b c}$ & $822.90^{\mathrm{b}}$ & $834.96^{\mathrm{a}}$ & 0.84 & 0.001 \\
\hline $\operatorname{Igm}(\mathrm{mg} / 100 \mathrm{ml})$ & $224.42^{\mathrm{d}}$ & $228.30^{c}$ & $236.36^{b}$ & $247.30^{\mathrm{a}}$ & 0.94 & 0.001 \\
\hline
\end{tabular}

a,b,c. means with the different letters in the same row are significantly different $(\mathrm{P} \leq 0.01)$; $\mathrm{SEM}=$ Standard error of means; GPX = glutathione peroxidase; $\mathrm{GSH}=$ glutathione; $\mathrm{SOD}=$ superoxide dismutase; $\mathrm{TAC}=$ total antioxidant capacity; Immunoglobulin $\mathrm{G}(\mathrm{IgG}), \mathrm{IgM}=$ Immunoglobulin. 
Fouad, W.;et al.

Table (5): Effect of propolis on some blood constituents of Japanese quail.

\begin{tabular}{|c|c|c|c|c|c|c|}
\hline Traits & control & $\begin{array}{c}\text { Propolis } \\
200 \\
\mathrm{mg} / \mathrm{kg} \\
\text { feed }\end{array}$ & $\begin{array}{c}\text { Propolis } \\
400 \mathrm{mg} / \mathrm{kg} \\
\text { feed }\end{array}$ & $\begin{array}{c}\text { Propolis } \\
600 \\
\mathrm{mg} / \mathrm{kg} \\
\text { feed }\end{array}$ & $\begin{array}{c}\text { Pooled } \\
\text { SEM }\end{array}$ & $\begin{array}{c}\mathbf{P} \\
\text { value }\end{array}$ \\
\hline Total protein $(\mathrm{g} / \mathrm{dl})$ & $3.57^{d}$ & $3.76^{c}$ & $4.22^{b}$ & $4.37^{\mathrm{a}}$ & 0.01 & 0.001 \\
\hline Albumin $\quad(\mathrm{g} / \mathrm{dl})$ & $1.64^{\mathrm{d}}$ & $1.75^{\mathrm{c}}$ & $2.09^{\mathrm{b}}$ & $2.11^{\mathrm{a}}$ & 0.01 & 0.001 \\
\hline Globulin $(\mathrm{g} / \mathrm{dl})$ & $1.94^{\mathrm{d}}$ & $2.01^{\mathrm{c}}$ & $2.13^{\mathrm{b}}$ & $2.26^{\mathrm{a}}$ & 0.01 & 0.001 \\
\hline Glucose, $(\mathrm{mg} / \mathrm{dl})$ & $176.66^{d}$ & $184.33^{c}$ & $191.67^{b}$ & $199.00^{\mathrm{a}}$ & 1.03 & 0.001 \\
\hline Total lipids (mg/dl) & $297.33^{a}$ & $286.33^{b}$ & $276.33^{c}$ & $267.00^{\mathrm{d}}$ & 1.09 & 0.001 \\
\hline Cholesterol (mg/dl) & $208.00^{a}$ & $203.33^{b}$ & $201.33^{b}$ & $189.33^{\mathrm{c}}$ & 0.88 & 0.001 \\
\hline $\mathrm{HDL} \quad(\mathrm{mg} / \mathrm{dl})$ & $67.33^{b}$ & $74.67^{c}$ & $80.33^{b}$ & $87.67^{\mathrm{a}}$ & 0.96 & 0.001 \\
\hline $\mathrm{LDL}(\mathrm{mg} / \mathrm{dl})$ & $118.33^{\mathrm{a}}$ & $110.00^{b}$ & $102.67^{c}$ & $95.33^{\mathrm{d}}$ & 0.88 & 0.001 \\
\hline $\operatorname{AST}(\mathrm{U} / \mathrm{L})$ & $55.67^{\mathrm{a}}$ & $47.67^{\mathrm{b}}$ & $44.33^{c}$ & $41.00^{\mathrm{d}}$ & 0.80 & 0.001 \\
\hline $\operatorname{ALT}(\mathrm{U} / \mathrm{L})$ & $20.90^{\mathrm{a}}$ & $19.40^{b}$ & $18.23^{c}$ & $17.70^{c}$ & 0.28 & 0.001 \\
\hline $\mathrm{T} 4$ (ng/ml) & 8.07 & 8.63 & 9.73 & 10.50 & 0.10301 & 0.001 \\
\hline $\mathrm{T} 3,(\mathrm{ng} / \mathrm{ml})$ & $1.98^{\mathrm{d}}$ & $2.02^{c}$ & $2.09^{\mathrm{b}}$ & $2.32^{\mathrm{a}}$ & 0.01 & 0.001 \\
\hline
\end{tabular}

a,b,c. means with the different letters in the same row are significantly different $(\mathrm{P} \leq 0.01)$;

$\mathrm{SEM}=$ Standard error of means

Table (6): Effect of propolis on on total anaerobic, aerobic count and total coliform of bacteria in intestine of Japanese quail.

\begin{tabular}{|c|c|c|c|c|c|c|}
\hline Treatments & control & $\begin{array}{c}\text { Propoli } \\
\text { s } 200 \\
\text { mg/kg } \\
\text { feed }\end{array}$ & $\begin{array}{c}\text { Propoli } \\
\text { s 400 } \\
\text { mg/kg } \\
\text { feed }\end{array}$ & $\begin{array}{c}\text { Propoli } \\
\text { s 600 } \\
\text { mg/kg } \\
\text { feed }\end{array}$ & $\begin{array}{l}\text { Poole } \\
\text { d } \\
\text { SEM }\end{array}$ & P value \\
\hline Total anaerobic count $\times 10^{2}$ & $0.80^{\mathrm{a}}$ & $0.67^{\mathrm{a}}$ & $0.36^{b}$ & $0.27^{b}$ & 0.05 & 0.002 \\
\hline Aerobic plate count $\times 10^{3}$ & $4.37^{\mathrm{a}}$ & $2.70^{\mathrm{b}}$ & $2.46^{\mathrm{b}}$ & $1.30^{\mathrm{c}}$ & 0.12 & 0.001 \\
\hline Total coliform Count $\times 10^{3}$ & $20.00^{\mathrm{a}}$ & $14.67^{\mathrm{b}}$ & $9.33^{c}$ & $3.00^{\mathrm{d}}$ & 0.68 & 0.001 \\
\hline
\end{tabular}

a,b,c. means with the different letters in the same row are significantly different $(\mathrm{P} \leq 0.01)$;

$\mathrm{SEM}=$ Standard error of means 


\section{REFERENCES}

A. P. H. A. American Public Health Association, 1985. Standard Methods for the Examination of Water and Wastewater, 16th Ed. APHA, Washington, D.C.

Abdel-Kareem, A. A. and El-Sheikh, T. M., 2015. Impact of supplementing diets with Propolis on productive performance egg quality traits and some hematological variables of laying hens. J. Anim. Physiol. Anim. Nutr., 28: 1-10.

Attia, Y.A.; Bovera F.; El-Tahawy W.S.; El-Hanoun A.M.; Al-Harthi M.A.; Habiba H. I., 2015. Productive and reproductive performance of rabbits does as affected by bee pollen and/or propolis, inulin and/or mannanoligosaccharides. World Rabbit sci. 2015, 23:273-282.

Attia, Y. A.; Abd Al-Hamid, A. E.; Ibrahim, M. S.; Al-Harthi, M. A.; Bovera, F. and El-Naggar, A., 2014. Productive performance, biochemical and hematological traits of broiler chicks supplemented with propolis, bee pollen and mannan oligosaccharides continuously or intermittently. Livest. Sci., 164: 8795.

Aygun,A.;Sert,D. and Copur, G., 2012. Effects of propolis on egg shell microbial activity, hatchability ,and chick performance in Japanese quail (Coturnix coturnix japonica) eggs.Poult.Sci.91,1018-1025.

Babaei, S.; Rahimi, S.; Torshizi, M. A. K.; Tahmasebi, G. and Khaleghi Miran, S. N., 2016. Effects of propolis, royal jelly, honey and bee pollen on growth Performance and immune system of Japanese quails. Vet. Res. 7 (1): $13-20$.

Canogullari, S.; Baylan, M.; Sahinler, N. and Sahin, A., 2009. Effects of propolis and pollen Supplementations on growth performance and body components of Japanese quails (Coturnix coturnix japonica). Archive fur Geflugelkunde. 73: 173-178.

Cetin, E.; Silici, S.; Cetin, N. and Guclu, B. K., 2010. Effects of diets containing different concentrations of propolis on hematological and immunological variables in laying hens. Poult. Sci., 89: 1703-1708.

Dimov, V; Ivanovska, N.; Manolova, N., 1991. Immuno- modulatory action of propolis. Influence on antiinfections protection and macrophage function. Apidologie; 22: 155-162.

Dimov, V.; Ivanovska, N.; Bankova, V. and Popov, S., 1992. Immunomodulatory action of propolis: IV. Prophylactic activity against gramnegative infections and adjuvant effect of the water-soluble derivative. Vaccine, 10: 817-823.

Dobrowolski, J. W.; Vohora, S. B.; Sharma, K.; Shah, S. A.; Naqvi, S. A. and Dandiya, P. C., 1991. Antibacterial, antifungal, antiamoebic, anti-inflammatory and antipyretic studies on propolis bee products. J. of Ethanopharm, 35: 7782.

Duncan, D. B., 1955. Multiple range and multiple F test. Biometrics. 11: 142.

Elnaggar, A. Sh. and Abd El-khalek, E., 2019. Impact of using propolis on performance, hematological and 
Fouad, W.;et al.

blood biochemical parameters and immune response of ducks (CAIRINA MOSCHATA). Egypt. Poult. Sci. Vol. (39) (III): (639-655).

Fischer, G.; Paulino, N.; Marcucci, M. C.; Siedler, B. S.; Munhoz, L. S.; Finger, P. F.; Vargas, G. D.; Hubner, S. O.; Vidor, T. and Roehe, P. M., 2010. Green propolis phenolic compounds act as vaccine adjuvants, improving humoral and cellular responses in mice Inoculated with inactivated vaccines. Mem. Inst. Oswaldo Cruz, 105: 908-913.

Freitas, J. A.; Vanat, N.; Pinheiro, J. W.; Balarin, M. R. S.; Sforcin, J. M. and Venacio, E. J., 2011. The effect of propolis on antibody production by laying hens. Poult. Sci., 90(6): 1227- 1233.

Freitas, S.F.; Shinohara, L.; Sforcin, J.M. and Guimarães, S., 2006. In vitro effects of propolis on Giardia duodenal istrophozoites. Phytomedicine, 13: 170-175.

Fuliang, H.U.; Hepburn, H.R.; Xuan, H.; Chen, M.; Daya, S., and Radloff, S.E., 2005. Effects of propolis on blood glucose, blood lipid and free radicals in rats with diabetes mellitus. Pharm. Resh., 51: 147-152.

Galal, A.; Abd El-Motaal, A. M.; Ahmed, A. M. H. and Zaki, T. G., 2008. Productive performance and immune response of laying hens as affected by dietary propolis supplementation. Inte. J. Poult. Sci., 7(3): 272-278.

Gekker, G., Hu, S.; Spivak, M.; Lokensgard, J. R. and Peterson, P. K., 2005. Anti-HIV-1 activity of propolis in $\mathrm{CD} 4(+)$ lymphocyte and microglial cell cultures. J. of

Ethanopharm., 102: 158-163.

Itavo, C. C. B. F.; Morais, M. G.; Costa, C.; Itavo, L. C. V.; Franco, G. L.; Da Silva, J. A. and Reis, F. A., 2011. Addition of propolis or momensin in the diet: Behavior and Productivity of lambs in feedlot. Anim. Feed Sci., Technol., 165: 161166.

Kacániová,M.; Arpásová,H.; C ubon,J.; Hleba,L.;Pochop,J.; Kunová, S.; Hascík,P., 2012. In vitro and in vivo anti-microbial activity of propolis on the microbiota from gastro intestinal tract of chickens. J. Environ. Sci. Health 47, 1665-1671.

Khalil, F.A. and El-Sheikh, N.M., 2010. The effects of dietary Egyptian propolis and bee pollen supplementation against toxicity of sodium fluoride in rats. J. Americ. Sci., 6 (11):310-316.

Khalil, M. L., 2006. Biological activity of bee propolis in health and disease. Asian Pac. J. Cancer Prev., 7: 22- 31.

Krol, W.; Czuba, Z.; Scheller, S.; Gabrys, J.; Grabiec, S.; Shani, J., 1990. Antioxidant property of ethanolic extract of propolis EEP as evaluated by inhibiting the chemil umine scence oxidation no fhuminal .Biochem. Int. 21,593-597.

Leja,M.; Mareczek,A.; Wyzgolik,G.; Klepacz,J.; Czekońska,K., 2007. Antioxidative properties of bee pollen in selected plant species. Food Chem. 100,237-240.

Mahmoud, Manal, A. M.; AbdelMohsein, H. S. and Farghali, M. R. F., 2015. Anti-Properties of Chinese propolis in Ross broiler exposed to heat stress in Egypt. Open 
propolis - Japanese Quail- growth - blood - immunity.

J. Vet. Medi., 5:197-209.

Mathivanan, V.; Shah, G. H.; Manzoor, M.; Mir, G. M.; and Selvisabhanayakam, 2013. A review on propolis- as a novel folk medicine. Ind. J. Sci., 2: 23-30.

Matsui, T.; Ebuchi, S. and Fujise, T., 2004. Strong antihyperglycemic effects of water-souluble fraction of brazillian propolis and its bioactive constituent, 3,4,5-tri-o-caffeoylquinic acid. biol Pharm ull 27, 1797-1803 .

Moreira, T. F., 1986. Chemical composition of propolis: Vitamins and amino acids. RevistaBrasileira de Farmacognosia, 1: 12-19.

Moreno MIN, Isla MI, Sampietro AR., 2000. Comparison of the free radical-scavenging activity of propolis from several regions of Argentina. J Ethnopharmacol; 71: 109-114.

Ojewole, G.S.; Uka S.N. and Onyenucheya, F., 2000. Comparative carcass characteristics of indigenous poultry feds different agro-industrial by-product, Tropical Journal of Anim. Sci., 3(2), 159 -161.

Olugbemi T. S.; Mutayoba, S. K. and Lekule, F. P., 2010. Effect of Moringa (Moringa oleifera) inclusion in cassava-based diets fed to broiler chickens. International Journal of Poultry Science, 9: 363-367. http://www.pjbs.org/ijps/fin1681.pdf

Omar, R.E. M.; Mahmoud, E. A.; Karousa, M. M. and Randa, S. A., 2014. Effects of Additives propolis and nigella sativa seed oil on some behavioural patterns, Performance products and blood parameters in Sasso chickens. World Poult. Sci.J., 70:140- 154.
Popiela-Pleban, E.; Roman, A,; Dobrzanski, Z; Pogoda-Sewerniak, K.; Opalinski, S. and Korczynski M., 2012. Effect of propolis and bee pollen supplementation on selected blood parameters of laying hens. WPC2012 - Salvador - Bahia - Brazil - 5 - 9 August - Book of Abstracts World'SPoult. Sci. J., Supplement 1, Expanded Abstract.

Šarić, A.; Balog, T.; Soboćance, S.; Kušis, B.; Šverko, V.; Rusak, G.; Likic, S.; Bubalo, D.; Pinto, B.; Real, D. and Marotti, T., 2009. Antioxidant effects of flavonoid from Crotain cystus in canus L. rich bee pollen. Food and Chemical Toxicology, 47: 547-554.

SAS Institute, 2002. SAS/STAT User's guide statistics. SAS institute INC., Cary. NC, USA.

Sforcin, J. M., 2007. Propolis and the immune system: a review.J Ethnopharmacol. $2007 \quad$ Aug 15;113(1):1-14.

Shalmany, S. K. and Shivazad, M., 2006. The effect of diet propolis supplementation on Ross broiler chick's performance. Int. J. Poult. Sci., 5: 84- 88.

Shreif, E.Y. and El-Saadany, A. S., 2017. Effect of supplementing diet with propolis on Bandarah chicks' performance. Egypt. Poult. Sci. Vol (37) (I): (169-184).

Tatli Seven, P.; Seven I.; Yilmaz M. and Simsek, U.G., 2008. The effects of Turkish Propolis on growth and carcass characteristics in broilers under heat stress. Anim. Feed Sci. Technol., 146: 137-148.

Tatli-Seven, P., 2008. The effect of dietary Turkish propolis and vitamin 
$\mathrm{C}$ on performance, digestibility, egg production and egg quality in laying hens under different environmental temperatures. Asian-Aust. J. Anim. Sci., 21(8):1164-117.

Tatli-Seven, P.; Yilmaz, S.; Seven. I.; Cerci, I. H.; Azman, M. A. and Yilmaz, M., 2009. The effect of propolis on selected blood indicators and antioxidant enzyme activities in broilers under heat stress. Acta Vet. Brno., 78:75- 83.

Velikova, M.; Bankova, V.; Tsvetkova, I.; Kujumgiev, A. and Marcucci, M. C., 2000. Antibacterial Ent-kaurene from Brazilian propolis of native stingless bee. Fytoterapia, 71: 693-690

Viuda-Martos, M.; Ruiz-Navajas, Y.; Fernández-López, J. and PérezÁlvarez, J. A., 2008. Functional properties of honey, propolis, and royal jelly. J. Food Sci., 73:R117R124.

Wagh, V. D., 2013. Propolis: A wonder bees product and its pharmacological potentials. Adv. Pharmacol. Sci., 2013, Article ID: 308249. httpn : // doi .org /10.1155/2013/308249.

Yang, Y.; Iji, P. A.; Kocher, A.; Thomson, E.; Mikkelsen L. L. and Choct, M., 2008. Effects of mannanoligosaccharide in broiler chicken diets on growth performance, energy utilisation, nutrient digestibility and intestinal microflora. British Poultry Science, 49: 186-194.

Zhang, K.Y. and Yan F, Keen, C.A., 2005. Evaluation of microencapsulated essential oils and organic acids in diets for broiler chickens. Int J Poult Sci; 4: 612-619. 


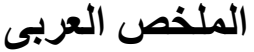

\section{تاثير اضافة البروبوليس على أداء النمو والاستجابات الفسيولوجية في السمان الياباني

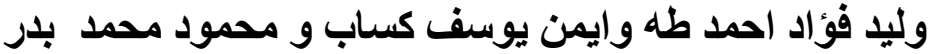

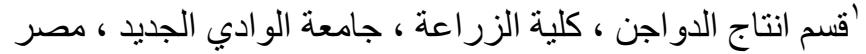

تمت دراسة تأثثير اضافة البروبوليس لاعلاف السمان اليابانى على اداء النمو وبعض مكونات الدم و الهرمونات

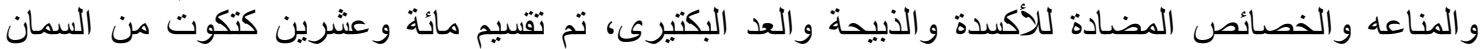

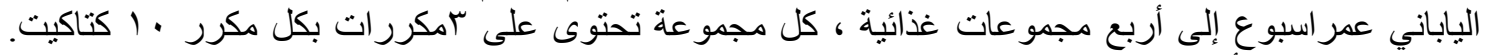

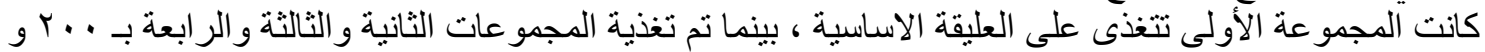

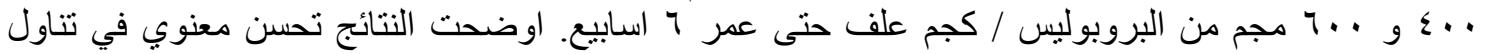

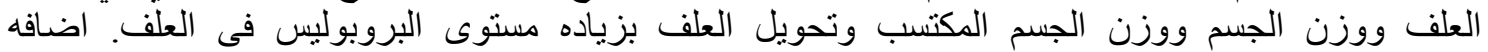

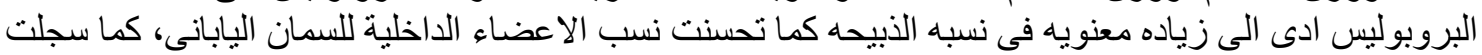

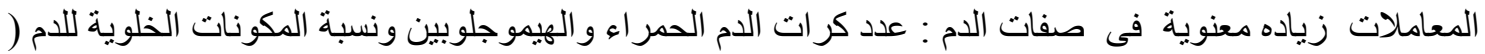

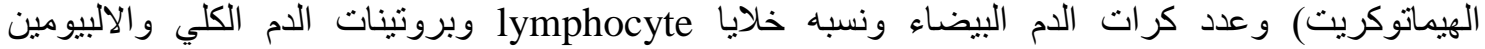

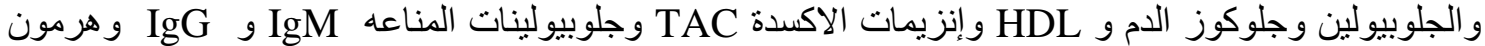

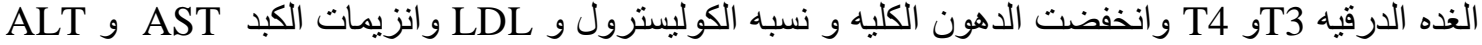

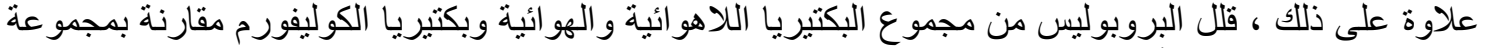

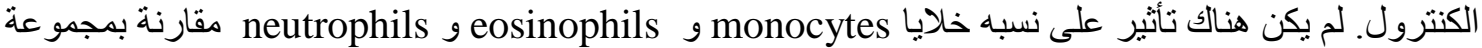

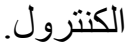
اوضحت النتائج أن إضافة البروبوليس بمستويات . . ب و . . ع و . 7 ملجم من البروبوليس / كجم علف حسن أداء النمو ومكونات الدم و مضادات الأكسدة وهرمونات الغدة الدرقية والاستجابه المناعية وخصائص الذبردية الذبيحة. 